\title{
WORKSHOP PERLINDUNGAN KEKAYAAN INTELEKTUAL SENI DAN BUDAYA LAMPUNG BAGI GURU SENI TINGKAT SMU/SMK PROVINSI LAMPUNG
}

\author{
Yunita Maya Putri ${ }^{1 *}$, Ria Wierma Putri ${ }^{2}$, Trisyanto ${ }^{3} \&$ Abdul Muthalib Tahar ${ }^{4}$ \\ 1,2,4 Program Studi lmu Hukum, ${ }^{3}$ Jurusan Ilmu Komputer, Universitas Lampung \\ J1. Prof. Dr. Soemantri Brodjonegoro No.1, Bandar Lampung, Lampung, Indonesia \\ *Korespondensi: yunita.maya@fh.unila.ac.id
}

\begin{abstract}
Abstrak
Sebagian besar masyarakat umum mengenal hak kekayaan intelektual (HKI) berupa hak cipta dan paten. Namun, perlindungan Hak Kekayaan Intelektual juga dapat diberikan pada produk seni budaya tradisional tidak hanya untuk inovasi saja. Guru seni (budaya) merupakan key actor yang terlibat secara langsung dalam memberikan pengajaran, melestarikan, dan mempraktekkan seni budaya. Namun, para guru seperti halnya masyarakat pada umumnya tidak mengetahui bahwa perlindungan Hak Kekayaan Intelektual berkaitan dengan profesi mereka sebagai guru seni. Oleh karena itu, diseminasi Hak Kekayaan Intelektual khususnya berkenaan dengan seni budaya sangat diperlukan. Sehingga terlaksananya tujuan untuk menyebarluaskan pengetahuan mengenai Hak Kekayaan Intelektual bagi guru seni se-Provinsi Lampung sebagai sasaran kegiatan
\end{abstract}

Kata kunci: Hak Kekayaan Intelektual, seni tradisional, budaya tradisional, guru seni

\section{ANALISIS SITUASI}

Hak kekayaan intelektual pada perkembangannya tidak hanya mengakui hak intelektual individu namun juga mengakui adanya hak kekayaan intelektual komunal. Pengakuan terhadap hak kekayaan intelektual komunal terdapat dalam Konvensi UNESCO 2003 yang mengatur warisan budaya tak benda sebagai praktek, representasi, ekspresi, pengetahuan, keterampilan serta instrumen-instrumen, obyek, artefak dan lingkungan budaya yang terkait meliputi berbagai komunitas, kelompok, dan dalam beberapa hal tertentu, perseorangan yang diakui sebagai bagian warisan budaya mereka. Warisan budaya tak benda ini, diwariskan dari generasi ke generasi, secara terus-menerus diciptakan kembali oleh berbagai komunitas dan kelompok sebagai tanggapan mereka terhadap lingkungannya, interaksi mereka dengan alam, serta sejarahnya, dan memberikan mereka makna jati diri dan keberlanjutan, untuk memajukan penghormatan keanekaragaman budaya dan kreatifitas manusia (Pasal 8, Convention for The Safeguarding of The Intangible Cultural Heritage, 2003). 
Negara melalui perundang-undangan nasionalnya, menghormati, melindungi dan mempertahankan pengetahuan, inovasi-inovasi dan praktik-praktik masyarakat asli dan lokal yang mencerminkan gaya hidup berciri tradisional, sesuai dengan konservasi dan pemanfaatan secara berkelanjutan keanekaragaman hayati dan memajukan penerapannya secara lebih luas dengan persetujuan dan keterlibatan pemilik pengetahuan inovasi-inovasi dan praktik-praktik semacam itu mendorong pembagian yang adil keuntungan yang dihasilkan dari pendayagunaan pengetahuan, inovasi-inovasi dan praktik-praktik semacam itu (Pasal 8 J Konvensi Keragaman Hayati tahun, 1992).

Keragaman budaya tradisional Indonesia dalam bentuk kebudayaan komunal dapat menjadi modal dasar pembangunan nasional. Namun intensitas interaksi dengan dunia luar yang semakin meningkat termasuk perdagangan yang semakin intensif dan tidak dapat dihindari memicu komersialisasi yang tidak adil dan berkelanjutan. Bahkan unsur budaya Indonesia menjadi rentan untuk diklaim oleh negara lain. Untuk itu diperlukan upaya nasional yang terintegrasi untuk merevitalisasi budaya nasional Indonesia. Diperlukan mekanisme komersialisasi budaya Indonesia pada system perdagangan internasional tanpa harus kehilangan identitas negara. Awal dari keberhasilan revitalisasi budaya dan komersialisasi keragaman budaya Indonesia adalah dengan membangun system hukum yang melindungi kekayaan budaya itu sendiri. Sedangkan sampai saat ini Indonesia belum mempunyai peraturan perundangan yang mengatur dan melindungi hak kekayaan komunal, untuk itu penulis akan mengkaji sejauh mana Perlindungan keanekaragaman budaya Indonesia melalui konsep Perlindungan hak kekayaan komunal.

Guru merupakan pelaku utama dalam melestarikan seni budaya tradisional Indonesia dengan mengajarkan tentang seni budaya tersebut, dan berkarya di bidang seni dan budaya. Namun, sebagian besar guru sebagai pendidik dan pencipta karya seni tidak menyadari dan mengetahui bahwa seni budaya dilindungi hak kekayaan intelektualnya serta dapat dikomersialkan. Oleh karena itu, banyak pelanggaran Hak Kekayaan Intelektual yang berkenaan dengan seni budaya. Untuk itu perlu disosialisasikan kepada para guru bahwa seni budaya tradisional maupun kontemporer diberikan perlindungan hak kekayaan intelektual. Maka dari itu sasaran pengabdian diberikan bagi seluruh guru-guru seni budaya tingkat SMU/SMK se Provinsi Lampung. 


\section{METODE PELAKSANAAN}

Workshop perlindungan Hak Kekayaan Intelektual untuk seni budaya Lampung yang diikuti oleh guru SMU/SMK se-Provinsi Lampung diberikan oleh tim sosialisasi dari Universitas Lampung yang dilaksanakan pada hari Selasa 1 Oktober 2019, pukul 08.00 wib sampai dengan 12.00 WIB di Taman Budaya Lampung serta diikuti oleh 60 orang peserta.

Model kegiatan ini dilakukan dengan teknik:

a. Ceramah, menyampaikan materi dan konsep berkenaan dengan hak kekayaan intelektual, ruang lingkup serta peraturan perundang-undangannya. Disertakan dengan power point dan video-video.

b. Diskusi, dilakukan setelah penyampaian materi selesai. Seluruh peserta diizinkan untuk memberikan pertanyaan terkait materi-materi yang telah disampaikan atau juga contoh-contoh kasus real yang dialami sendiri oleh para peserta selama menjalani profesinya.

c. Pre test dan post test, hal ini dilakukan untuk mengetahui sejauh mana pemahaman peserta terkait hak kekayaan intelektual sebelum dan sesudah diberikan materi.

\section{PELAKSANAAN DAN HASIL}

Kegiatan dibuka oleh Kepala UPTD Taman Budaya Lampung. Sebelum penyampaian materi, peserta diberikan pre test terkait pengetahuan mengenai hak kekayaan intelektual. Hasil pre-test dan post-test yang dilakukan pada 60 peserta dengan pertanyaan berikut:

a. Apakah Anda mengetahui tentang Hak Kekayaan Intelektual dan apa saja bentuk Hak Kekayaan Intelektual?

b. Apakah Anda mengetahui perlindungan Hak Kekayaan Intelektual untuk seni dan budaya?

c. Menurut Anda apakah profesi Anda memerlukan Hak Kekayaan Intelektual?

Hasil pre-test menunjukkan 90 persen menyatakan pernah mendengar Hak Kekayaan Intelektual tetapi tidak mengerti, tidak mengetahui bahwa seni budaya dilindungi oleh Hak Kekayaan Intelektual dan tidak merasa bahwa Hak Kekayaan Intelektual berkaitan dengan profesinya sebagai guru. Setelah mendengarkan materi, berdiskusi, dan tanya jawab, para guru mengetahui bahwa Hak Kekayaan Intelektual tidak hanya paten dan hak cipta, Hak Kekayaan Intelektual juga memberikan perlindungan untuk seni dan budaya tradisional serta kontemporer. Selain itu, para guru mengetahui 
bahwa sebagai guru mereka dapat memperoleh manfaat perlindungan Hak Kekayaan Intelektual dari karya dan aktifitas mereka dalam bidang seni dan budaya.

\section{PENUTUP}

Kegiatan pengabdian masyarakat terselenggara dengan baik dan mendapatkan antusias dari para peserta hal ini terlihat dari banyaknya peserta yang mengajukan pertanyaan. Selain itu mereka juga meminta agar penyuluhan terkait perlindungan Hak Kekayaan Intelektual ini dapat diberikan lagi dilain kesempatan.

\section{UCAPAN TERIMA KASIH}

Tim pengabdian mengucapkan terima kasih yang sebesar-besarnya kepada Taman Budaya Lampung yang telah mengkoordinir kegiatan ini hingga berjalan dengan lancar serta kepada seluruh guru-guru tingkat SMU/SMK se Provinsi Lampung yang telah bersedia untuk mengikuti kegiatan pengabdian ini.

\section{DAFTAR PUSTAKA}

Convention for The Safeguarding of The Intangible Cultural Heritage 2003

Hadjon, P. M.. (1987). Perlindungan Bagi Rakyat di Indonesia. Surabaya: PT.Bina Ilmu.

Konvensi Keragaman Hayati tahun 1992

Marzuki, P. M. (2008). Pengantar Ilmu Hukum. Jakarta:Kencana.

Undang-undang tentang Hak Cipta Nomor 28 Tahun 2014 